\title{
Novel Quinazoline Derivatives Targeting on EGFR Kinase Mediated Signal Pathway in A431 Human Epidermoid Carcinoma Cells
}

\author{
Chul Woo Jeong ${ }^{1}$, Byeng Wha Son ${ }^{2}$, Jae Du Ha ${ }^{3}$ and Gun-Do Kim ${ }^{1}$. \\ ${ }^{1}$ Department of Microbiology, College of Natural Sciences, Pukyung National University, Busan 608-737, Korea \\ ${ }^{2}$ Department of Chemistry, College of Natural Sciences, Pukyung National University, Busan 608-737, Korea \\ ${ }^{3}$ Korea Research Institute of Chemical Technology, Daejeon 305-343, Korea.
}

Received March 15, 2011/Accepted March 24, 2011

\begin{abstract}
Inhibitors of EGFR (epidermal growth factor receptor) kinase activity may prove useful to therapeutically intervene in cancer and to treat other proliferative diseases. In this study, we investigated the inhibitive effects of two compounds named 63013 and 63033 possess a [1,4]-dioxino quinazoline structure that links the alkoxy side chains together and their structural characteristics are considered to allow better solubility than the dialkoxyquinazoline derivatives. The EGFR kinase activities of A431 human epidermoid carcinoma cells, stimulated by EGF were inhibited by treatment with 63013 and 63033 in a dose-dependent manner respectively. Consistent with the compound-mediated EGFR kinase suppression, the major EGF-related downstream target molecules, such as MEK1/2, MAPK p44/42, AKT and STAT3, were also suppressed by both compounds. Interestingly, both compounds led to cell growth inhibition at a lower concentration than that of Gefitinib (Iressa ${ }^{\circledR}$ ). Collectively, our study showed that both compounds may have good therapeutic potential as an EGFR kinase specific inhibitor to treat EGFR-related diseases.
\end{abstract}

Key words : EGFR kinase, Gefitinib (Iressa ${ }^{\circledR}$ ), MEK1/2, AKT, STAT3

Introduction

Epidermal Growth Factor Receptor (EGFR) is a kind of type 1 receptor tyrosine kinase or ErbB receptor [5], and EGFRs are classified into four kinds, namely, EGFR (ErbB1/EGFR/HER1), ErbB2 (HER2/neu), ErbB3 (HER3) and ErbB4 (HER4) [13]. ErbB receptors can be divided into the extracellular ligand-binding domain, the transmembrane domain and intracellular tyrosine kinase (TK) domain. When ligand is bound to the ErbB receptor, this forms homo- dimetric or hetero-dimetric complexes and then the intracellular tyrosine kinase domain is phosphorylated. The phosphorylation leads the activation of the intracellular signal transductions of Ras-Raf-MAP-kinase, phosphatidylinositol 3-kinase (PI3K) and stress-activated protein kinase (protein kinase C \& Jak/Stat) [2,11]. Activation of the EGFR leads to receptor-associated tyrosine kinase activity that stimulates a cascade of events such as cell cycle progression, as well as a number of other processes that are crucial to cancer progression [9].

The EGFR plays an important role in regulating cellular

*Corresponding author

Tel: +82-51-629-5618, Fax: +82-51-629-5619,

E-mail: gundokim@pknu.ac.kr processes such as proliferation, differentiation and survival, and EGFR is critical to the maintenance of normal epidermal tissues where its expression is highly regulated [10]. The over-expression and loss of self-regulation of EGFR gives rise to various solid tumors, including breast, colorectal, ovarian and non-small-cell lung cancer (NSCLC) [15]. Furthermore, it has been reported that when EGFR is over-expressed, it activates the signaling transduction system and so cancer cells grow more aggressively, and with their increased invasiveness, metastasis occurs more easily and this has negative effects to the survival rate $[1,8]$. Therefore, the inhibitors that prevent EGFR kinase activity can be effective for treating cancer and other proliferative diseases. In this respect, a variety of studies on inhibitors has recently been conducted $[6,12,14]$. The EGFR-targeted therapies being developed include those that interact with the extracellular ligand-binding domain, and those that act intracellularly, such as the small-molecule EGFR tyrosine kinase inhibitors (EGFR-TKIs) that compete with ATP to bind to the receptor's ATP site.

Quinazoline is a compound that's made up of two fused six-member simple aromatic rings, that is, a benzene ring and a pyrimidine ring. Medicinally it has been used for treating various diseases, and especially as an anti-malarial agent 
and in cancer treatment. However, quinazoline has poor bioavailability in vivo because of its low water solubility. So, to heighten the bioavailability, numerous studies on quinazoline derivatives have been conducted by researchers. Both compounds 63013 and 63033 possess a [1,4]-dioxino quinazoline structure linking the alkoxy side chains together, and their structural characteristics are considered to have better solubility than the dialkoxyquinazoline derivatives [7].

The purpose of this study was to investigate the inhibitory effects on EGFR kinases and on the activities of the EGF-related downstream molecules by these 2 quinazoline $\mathrm{de}^{-}$ rivatives (63013 and 63033).

\section{Materials and Methods}

\section{Cell culture}

The media and cell culture reagents were purchased from GIBCO BRL (Gaithersburg, MD, USA). The A431, HeLa, and HEK293 cells were cultured in DMEM supplemented with $10 \%$ fetal bovine serum (FBS), $100 \mathrm{U} / \mathrm{ml}$ penicillin and 100 $\mu \mathrm{g} / \mathrm{ml}$ streptomycin (Life Technologies Inc., Rockville, MD, USA) at $37^{\circ} \mathrm{C}$ in a $5 \% \mathrm{CO}_{2}$ atmosphere. The A549 cells and HT-29 cells were cultured in RPMI-1649 that contained 10\% FBS, $100 \mathrm{U} / \mathrm{ml}$ penicillin and $100 \mu \mathrm{g} / \mathrm{ml}$ streptomycin at the same conditions as mentioned above. The HUVEC cells were grown in liquid-endothelial cell basal medium-2 (EBM-2) that was purchased from Cambrex Bio Science (Walkersville, $\mathrm{MD}, \mathrm{USA}$ ) and it contained various growth factors [20 $\mathrm{ml}$ of (20\%) FBS, hydrocortisone (0.2 ml), hFGF (2 ml), vEGF (0.5 ml), R3-IGF (1.05 ml), ascorbic acid (0.5 ml), hEGF (0.5 $\mathrm{ml})$, GA-1000 $(0.5 \mathrm{ml})$ and heparin $(0.5 \mathrm{ml})]$. The SK-Br-3 cells were cultured in McCoy's $5 \mathrm{~A}$ medium that was supplemented with $10 \%$ FBS. The cells were maintained by subculture in a T75 flask. For the experiments, the confluent cells were subcultured in $6 \mathrm{~cm}$ dishes before performing the experiments.

\section{Synthesis of compounds}

After dihydroxybenzoate ethylester 1 and epichlorohydrin were dissolved in ethanol followed by heated and refluxed for $10 \mathrm{hr}$ in the presence of $\mathrm{Na}_{2} \mathrm{CO}_{3}, 3$-hydroxymethyl dihydrobenzodioxane 2 was obtained at a 95\% yield rate. Compound 2 was treated with sodium hydride $(\mathrm{NaH})$, and then methyl iodide $(\mathrm{Mel})$ and benzyl bromide $(\mathrm{BnBr})$ were added to it, and the $\mathrm{O}-$ alkylation compounds $3 \mathrm{a}$ and $3 \mathrm{~b}$ were obtained at about a 90\% yield rate (Fig. 1). The desired com- pounds 63013 and 63033 were manufactured by the methods reported previously [7].

\section{Antibodies}

Anti-EGFR (pY845, pY992, pY1045, pY1068 and total-EGFR), anti-STAT3 (pY705, pS727 and total-STAT3), anti-MEK 1/2 (pS217/221 and total-MEK 1/2), anti-MAPK p44/42 (pT202/pY204 and total-MAPK p44/42), anti-AKT (pT308, pS473 and total-AKT), anti-PDK1 (pS241 and total-PDK1) and horseradish peroxidase-coupled anti-rabbit IgG (anti-mouse $\operatorname{Ig} G$ ) antibodies were purchased from Cell Signaling Technology Inc. (Beverly, MA, USA). Antibody against phospho-tyrosine residue 1173 of the EGFR was purchased from Calbiochem (San Diego, CA, USA).

\section{Cell viability assay}

The cells were seeded in 96 well plates at $5 \times 10^{3}$ cells/well (test for cell proliferation) or $1 \times 10^{4}$ cells/well (test for cytotoxicity) and each compound had been pre-added as described in the figure legends, and the cells were then cultured in the appropriate medium for $48 \mathrm{hr}$. The proliferative effects of each compound against the various cell lines were determined by a 3-(4,5-dimethylthiazol-2-yl)-2,5-diphen-yltetrazolium bromide (MTT) assay that measures cell proliferation based on the ability of live cells bind to MTT and converts it to dark blue. The number of metabolically active cells was determined by measuring the absorbance at 570 nm with ELISA reader (Molecular Devices, Silicon Valley, CA, USA).

In vitro kinase assay for tyrosine residues in EGF receptor

EGF receptor tyrosine kinase assay was performed using an AlphaScreen ${ }^{\circledR}$ P-Tyr-100 assay kit system. Purified EGFR (affinity purified from human carcinoma A431 cells) was purchased from SIGMA (St. Louis, MO, USA). Substrate (poly [Glu:Tyr] (4:1)) and the AlphaScreen ${ }^{\circledR}$ P-Tyr-100 assay kit were purchased from Packard BioScience company (Shelton, CT, USA). The kinase reactions were performed in a mix of EGFR enzyme, ATP and biotinylated poly [Glu:Tyr] (4:1) in kinase buffer [50 mM Tris (pH7.5), $5 \mathrm{mM}$ $\mathrm{MgCl}_{2}, 5 \mathrm{mM} \mathrm{MnCl}, 2 \mathrm{mM}$ DTT and 0.01\% Tween-20]. The mixture was incubated for $1 \mathrm{hr}$ at room temperature and the reaction was quenched by adding detection buffer that containing EDTA, Donor-Streptavidin and Acceptor-P-tyr100 beads. This was allowed to incubate for $1 \mathrm{hr}$ at RT and 


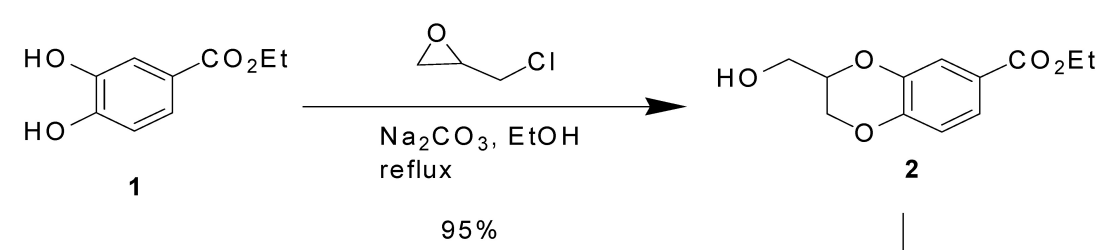

$\mathrm{NaH}, \mathrm{Mel}$ or $\mathrm{BnBr}$
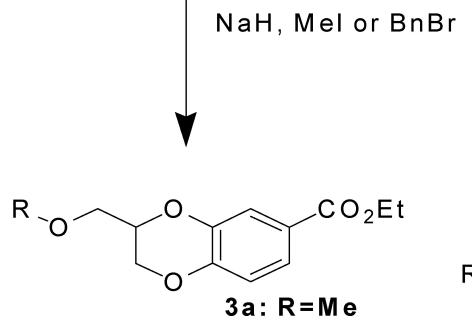

$\mathrm{R}=\mathrm{Me}$ or $\mathrm{Bn}$

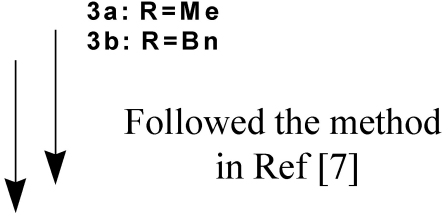

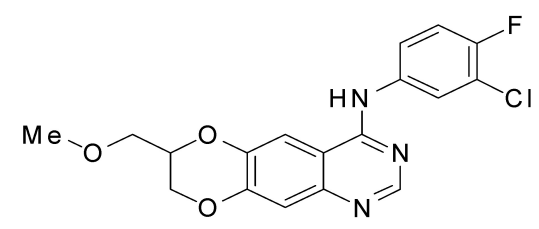

63013

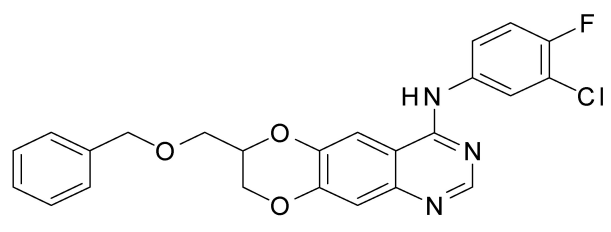

63033

Fig. 1. Synthesis of 63013 and 63033. Compounds 63013 and 63033 were manufactured from 3a and 3b followed by the method reported previously [7].

then the intrinsic kinetic activities were detected as AlphaScreen ${ }^{\otimes}$ signals with using a Fusion alpha microplate analyzer (PerkinElmer, Shelton, CT, USA).

\section{Western Blot Analysis}

The cells were pre-cultured with the indicated compound for $45 \mathrm{~min}$ and then they were treated with $5 \mathrm{nM}$ EGF (epidermal growth factor) for $10 \mathrm{~min}$. To prepare the whole cell lysates, the cells were washed twice with cold-PBS and then they were lysed by ice-cold lysis buffer [50 mM Tris-Cl (pH 7.5), $150 \mathrm{mM} \mathrm{NaCl}, 1 \mathrm{mM}$ DTT, 0.5\% NP-40, 1\% Triton X-100, 1\% Deoxycholate, $0.1 \%$ SDS and proteinase inhibitors (PMSF, EDTA, Aprotinin, Leupeptin, Prostatin A)] (Intron biotechnology, Gyeonggi, Korea). After incubation on ice for $30 \mathrm{~min}$, the insoluble materials were removed by centrifugation at 14,000 rpm for $20 \mathrm{~min}$. The protein content of the cell lysates were determined by a Protein Quantification Kit (CBB solution ${ }^{\circledR}$ ) (Dojindo Molecular Technologies, Rockvile, MD, USA) with bovine serum albumen (BSA) as standard. Each sample was boiled with SDS-sample buffer [6.25 mM Tris- $\mathrm{HCl}$ (pH 6.8), 2\% (w/v)
SDS, $10 \%$ glycerol, $50 \mathrm{mM}$ DTT and $0.1 \%(\mathrm{w} / \mathrm{v})$ bromophenol] for 5 min followed by electrophoresis on an $8 \%$ or $10 \%$ sodium dodecyl sulfate (SDS)-polyacrylamide gel. The resolved proteins were transferred onto nitrocellulose membranes (PALL Life Sciences, MI, USA) and then blocked with PBST buffer (135 mM Sodium chloride, $2.7 \mathrm{mM}$ Potassium chloride, $4.3 \mathrm{mM}$ Sodium phosphate, $1.4 \mathrm{mM}$ Potassium dihydrogen phosphate, $0.5 \%$ Tween-20) contained 5\% skim milk for $1 \mathrm{hr}$ at room temperature. The blots were further incubated with the primary antibody diluted in the blocking buffer (PBST buffer contained 1\% skim milk) for overnight at $4^{\circ} \mathrm{C}$, washed twice in PBST, incubated with the horseradish peroxidase-coupled second antibody in the blocking buffer for $1 \mathrm{hr}$ and rewashed twice with PBST buffer. The blotted proteins were detected by using the enhanced chemiluminescence detection system (Pierce, Rockford, IL, USA).

Cell-based assay for phosphorylated tyrosine residue in EGF receptor

For detecting the phosphorylated tyrosine residue (pY992) in EGF receptors, we used cell-based ELISA kits from Active 
Motif (Carlsbad, CA, USA) according to the manufacturer's recommended procedure. A431 cells were seeded in 96-well plate at $1 \times 10^{4}$ cells/well. When the cells were ready to treated, pre-treated with each compound for 45 min and further incubated in the presence or absence of $5 \mathrm{nM}$ EGF for $10 \mathrm{~min}$. The cells were fixed with $4 \%$ formaldehyde in PBS for $20 \mathrm{~min}$ at room temperature and then they were washed three times with washing buffer ( $1 \times$ PBS that contained 0.1\% Triton $\mathrm{X}-100)$. The endogenous peroxidase activity was quenched by adding washing buffer that contained $1 \% \mathrm{H}_{2} \mathrm{O}_{2}$ and $0.1 \%$ Azide for $20 \mathrm{~min}$. The cells were then washed three times in washing buffer, they were blocked with $10 \%$ fetal calf serum in washing buffer for $1 \mathrm{hr}$ and they were incubated overnight at $4^{\circ} \mathrm{C}$ with phospho-specific EGFR antibody that was diluted $1 / 200$ with dilution buffer. The next day, the cells were washed three times with washing buffer for 5 min each time and then they were incubated with sec- $^{-}$ ondary antibody (peroxidase-conjugated anti-rabbit antibody diluted 1/100) for $1 \mathrm{hr}$ at room temperature. They were washed again three times with washing buffer for $5 \mathrm{~min}$ each time and then they were washed twice with PBS. Subsequently, the cells were incubated at room temperature with $50 \mu$ of chemiluminescent working solution that was placed in each well. The luminescence activity was measured by a luminometer. All the experiments were performed in duplicate.

\section{Results and Discussion}

\section{Inhibitory effects on the EGFR tyrosine kinase activity}

The effects of new quinazoline derivative compounds 630 13 and 63033 on the EGFR kinase activity were examined in the A431 human epidermoid carcinoma cells (Fig. 2). Gefit inib (Iressa ${ }^{\circledR}$ ), a well-known strong inhibitor of EGFR-activit y was used as the positive control group. Gefitinib (Iressa ${ }^{\circledR}$ ) is a kind of Quinazoline derivative that contains a morpholin yl propoxy group at $\mathrm{C}-6$. Gefitinib has oral activity and is the most effective and selective EGFR inhibitor [12]. Using the AlphaScreen ${ }^{\circledR}$ P-Tyr-100 assay system, the activity of EG $\mathrm{F}$ receptor tyrosine kinase was measured in vitro. Each comp ound has $50 \%$ inhibition on the activity at a $7 \mu \mathrm{M}$ concentrati on, which shows the modality of concentration-dependent inhibition. Like Gefitinib as a positive control, both the comp ounds 63013 and 63033 have EGFR inhibiting effects on the enzyme assay and on the cell-based
A

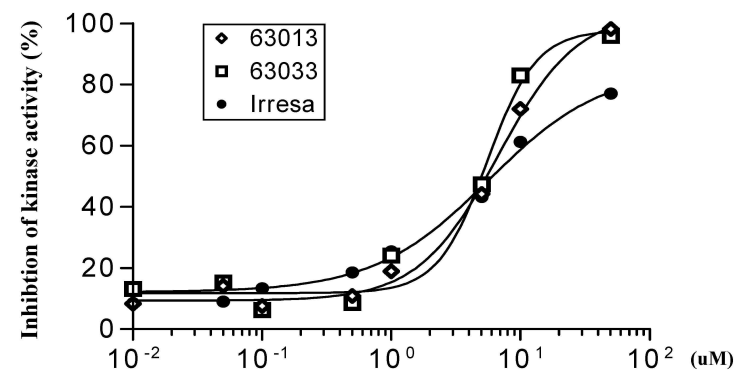

B

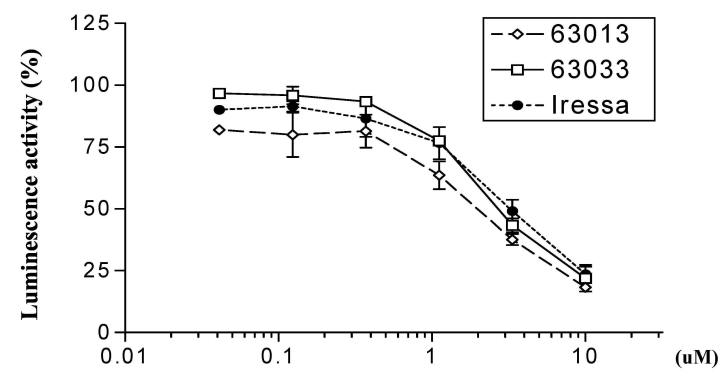

Fig. 2. The activity of EGF receptor tyrosine kinase by 63013 and 63033. (A) In vitro enzyme assay. (B) The cell-based assay for phosphorylated tyrosine residue of EGFR. Each compound 63013 (open diamond), 63033 (open quadrangle), and Gefitinib (Iressa®) (as a positive control, closed circle) are indicated. Purified EGFR from human carcinoma A431 cells (A) and the A431 cells (B) were treated with various concentrations of each com- $^{-}$ pound as indicated.

assay (Fig. 2A, 2B). The results suggested these two compounds have excellent ability to penetrate the cell membrane and they have a potency can be used as drugs with further development.

The effect on phosphorylation of each tyrosine residues in EGFR

For full activation, EGFR requires cooperative translocation into the plasma membrane to form dimeric and $\mathrm{mu}^{-}$ timeric EGFR complexes, and autophosphorylation is also required for opening the various tyrosine residues in order to induce the signals to several downstream kinases in the cytosol [11]. EGFR inhibitors, including the quinazoline derivatives, inhibit phosphorylation of the tyrosine residues through completion with ATP in the ATP binding pocket of EGFR [7]. We first examined the expression level of EGFR in A431 and HeLa cell lines, originated from human small lung cancer and uterine cervical cancer, respectively. We tested whether the EGFR of the A431 cells has functional active when stimulated with $5 \mathrm{nM}$ EGF (Fig. 3A). Next, we 
A

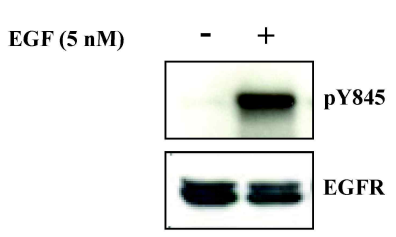

$\mathbf{B}$

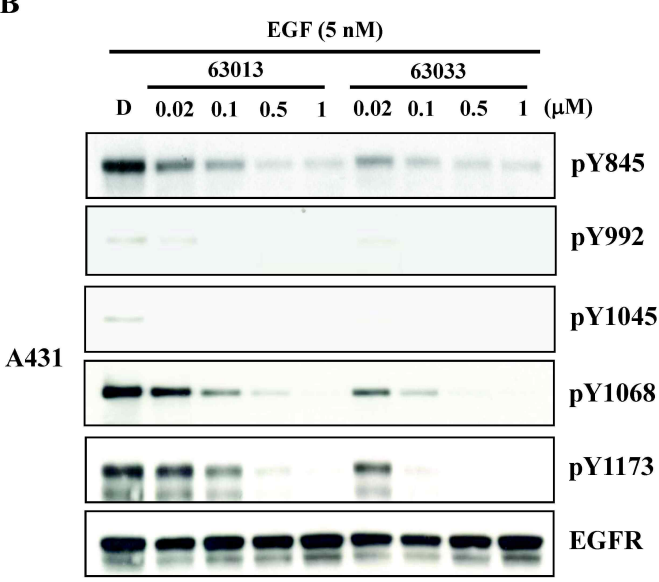

C

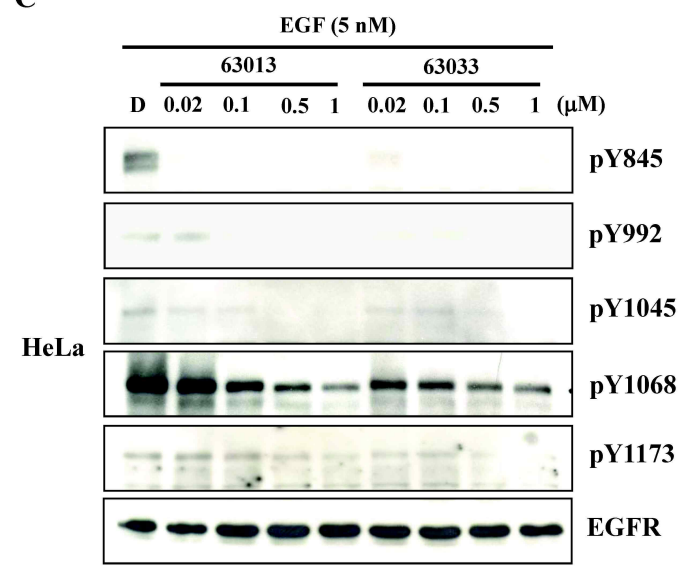

Fig. 3. The effects of compounds on the phosphorylation of tyrosine residues of EGFR. (A) The A431 cells were treated with or without $5 \mathrm{nM}$ EGF for $10 \mathrm{~min}$ and the results were detected by using phosphorylated EGFR antibody against tyrosine residue 845. The A431 cells (B) and HeLa cells (C) were pre-treated with compounds and DMSO (designated as D) at the indicated concentrations and then the cells were incubated with 5 nM EGF for 10 min. The EGFR phosphorylation on Tyr-845, Tyr-992, Tyr-1045, Tyr-1068 and Tyr-1173 were subjected to immunoblotting with antibodies that recognize various phosphorylated tyrosine residues in EGFR.

examined the inhibitory effects of both compounds on the EGFR activities by performing Western blot analysis with the protein extracts of A431 and HeLa cells respectively. The EGF-stimulated EGFR phosphorylation was suppressed by treatment with both compounds in a dose-dependent manner, although there were differences of the inhibition rates between 63013 and 63033 (Fig. 3B, 3C). These results indicate that both compounds have effective potential as EFGR inhibitors acting on the inhibition of phosphorylation on tyrosine residues in EGFR.

The effect on the EGF-related downstream molecules

When EGFR that's bound with EGF is activated, the EGF-related downstream molecules such as MEK 1/2, MAPK p44/42, PDK1 and STAT3 are phosphorylated [2,11]. In this respect, we tested whether the two compounds suppressed the activity of each molecule with using antibodies that recognize the phosphorylation of each residue in MEK 1/2, MAPK p44/42, PDK1 and STAT3 (Fig. 4A, 4B, 4C). The A431 cells, which were pre-treated with the two compounds at the concentrations indicated in Figure 4, were incubated for $10 \mathrm{~min}$ in the presence of $5 \mathrm{nM} \mathrm{EGF}$. Using antibodies that recognize the phosphorylation of MEK 1/2, MAPK $\mathrm{p} 44 / 42$, PDK1 and STAT3, experiments were conducted to determine whether the two compounds inhibited the activity of each molecule. In the case of MAPK p44/42, while the 63013 compound suppressed phosphorylation of the pT202/pY204 residue at the $1 \mu \mathrm{M}$ concentration, the 63033 compound did not show any suppressing effects (Fig. 4A). Therefore, we suggest that there is a little difference in their operating principles to inhibit EGFR, although the two compounds 63033 and 63013 have a similar structure. In the case of PDK1, the compounds 63033 and 63013 did not inhibit phosphorylation of a residue (Fig. 4B). In case of STAT3, both compounds shown the preference for the tyrosine residue compared to the serine residue (Fig. 4C). The results show that the two compounds inhibit the activities of MEK 1/2, MAPK p44/42 and STAT3 (Fig. 4A, 4C).

$$
\begin{aligned}
& \text { Comparison of the inhibitory activity to Gefitinib } \\
& \text { (Iressa }{ }^{\circledR} \text { ) }
\end{aligned}
$$

The inhibitory activity of compounds 63013 and 63033 on 
A

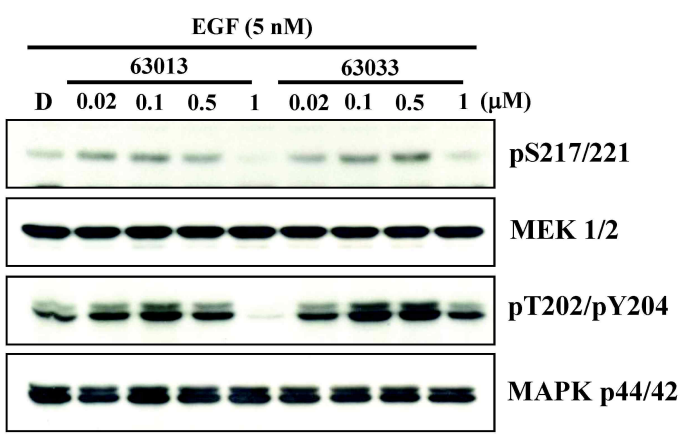

B

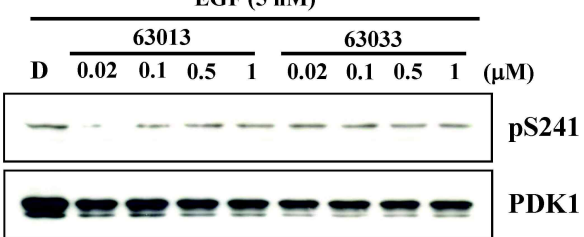

C

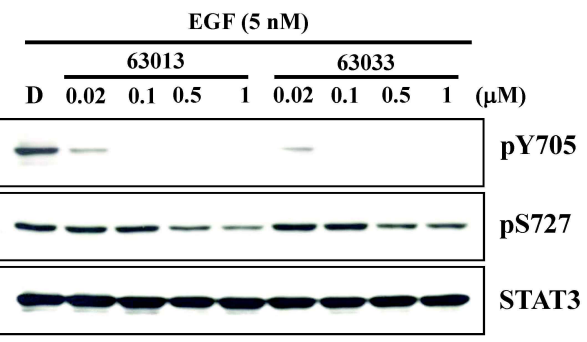

Fig. 4. Compounds 63013 and 63033 inhibited the activities of MEK1/2, MAPK p44/42, PDK1 and STAT3. Serum-starved A431 cells were pre-treated with both compounds or with DMSO (designated as D) and then incubated with $5 \mathrm{nM}$ EGF for 10 min. The phosphorylated and the total of MEK 1/2 (A), MAPK p44/42 (A), PDK1 (B), and STAT3 (C) proteins were detected by immunoblotting with antibodies that recognize the specific phosphorylation site and the total of each protein.

A

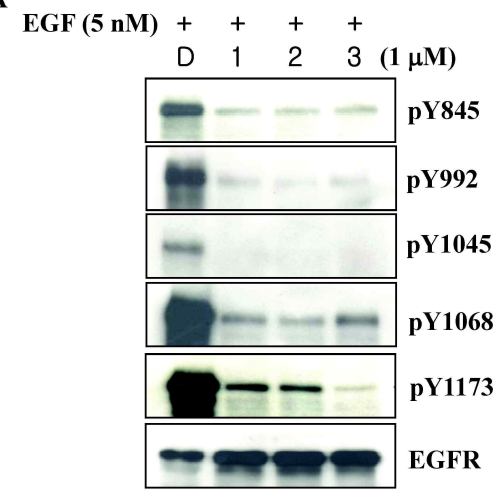

D : DMSO

$1: 63013$

$2: 63033$

3 : Gefitinib (Iressa $\left.{ }^{\circledR}\right)$
B

$\operatorname{EGF}(5 \mathrm{nM})+\quad+\quad+\quad+$

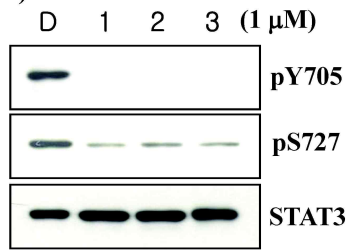

C

$\operatorname{EGF}(5 \mathrm{nM})++\quad+\quad+$

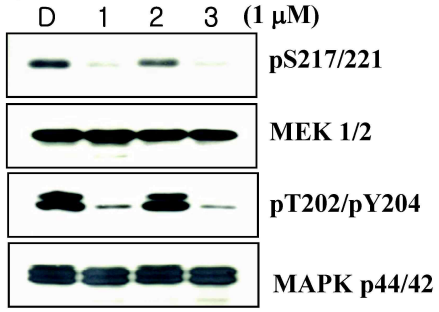

D

$\operatorname{EGF}(5 \mathrm{nM})+\quad+\quad+\quad+$

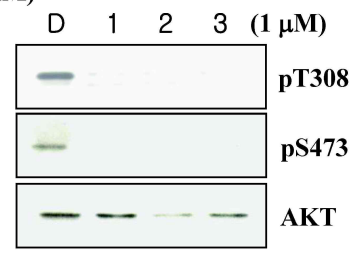

Fig. 5. Comparison of the inhibitory activities of 63013 and 63033 to Gefitinib on the phosphorylation of tyrosine residues in EGFR and EGF-related downstream molecules. The A431 cells were pre-treated with $1 \mu \mathrm{M}$ of each compound followed by stimulation with $5 \mathrm{nM}$ EGF for $10 \mathrm{~min}$. The results shown in the figure were detected by Western blot analysis with the various phospho-specific antibodies of EGFR (A). The expression of the specific phosphorylated and the total of each EGF-related downstream molecules such as STAT3 (B), MEK 1/2 (C), MAPK p44/42 (C), and AKT (D) proteins were compared. 
the EGFR and EGF-related downstream molecules was compared with that of Gefitinib (Iressa ${ }^{\circledR}$ ), which was used as a control, and Gefitinib has been previously reported to be a strong EGFR inhibitor [12]. The A431 cells were pre-treated with $1 \mu \mathrm{M}$ concentrations of each compound, and then the cells were further incubated for $10 \mathrm{~min}$ in the presence of $5 \mathrm{nM}$ EGF. DMSO was used as a positive control. The two compounds showed almost the same phosphorylation inhibition effects on the tyrosine residues of EGFR as did Gefitinib. In fact, the two compounds 63033 and 63013 sometimes showed stronger inhibiting effects than those of Gefitinib (Fig. 5A). Moreover, the two compounds also showed almost the same activity inhibition effects on the EGF-related downstream molecules, such as STAT3 (Fig. 5B), and AKT (Fig. 5D), as Gefitinib did. For MEK1/2 and MAPK p44/42, while 63013 showed very similar effects with those of Gefitinib, 63033 had relatively weaker inhibiting effects as compared to those of Gefitinib (Fig. 5C).
The effects on EGF-induced cell growth and cytotoxicity

EGFR activated by EGF is involved in the growth of cells $[3,4]$. To examine whether or not EGF induces the growth of cells, we applied human cell lines that have been reported to express EGFR, such as A431, HeLa, A549, and SK-BR-3, and the growth of cells (\%) was assessed by performing an MTT assay (Fig. 6A, 6B). Each cell line $\left(5 \times 10^{3}\right.$ cells) was cultured in media that contained $5 \mathrm{nM}$ EGF in presence or $\mathrm{ab}^{-}$ sence of $10 \%$ fetal bovine serum for $48 \mathrm{hr}$ at $37^{\circ} \mathrm{C}$ in $5 \%$ $\mathrm{CO}_{2}$ and we used cells that were cultured without EGF as a negative control. In each investigation with using media that contained serum and serum-free media, most of the cell lines showed growth of cells in the condition where EGF existed. Especially, the A431 cells showed the highest growth rate of cells. (Fig. 6A, 6B) The concentration of EGF that can most effectively induce the growth of cells was examined (Fig. 6C). A431 cells, which showed the highest growth rate of cells, were selected as the cell line. The A431 cells were incubated in DMEM that contained various con-
A

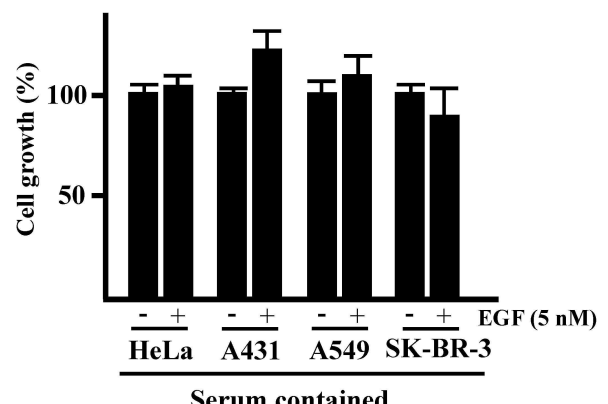

Serum contained
B

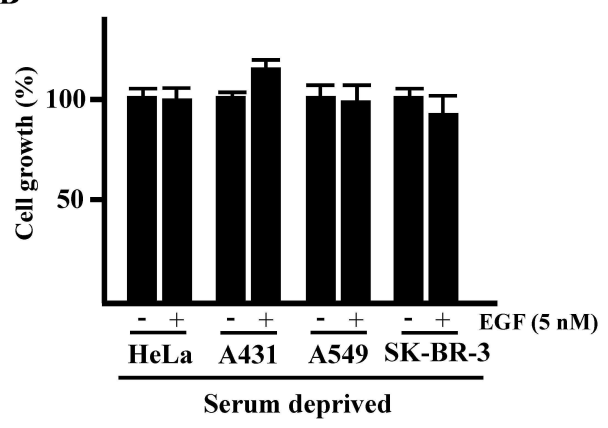

C

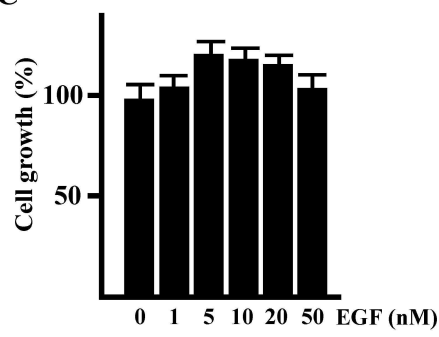

D

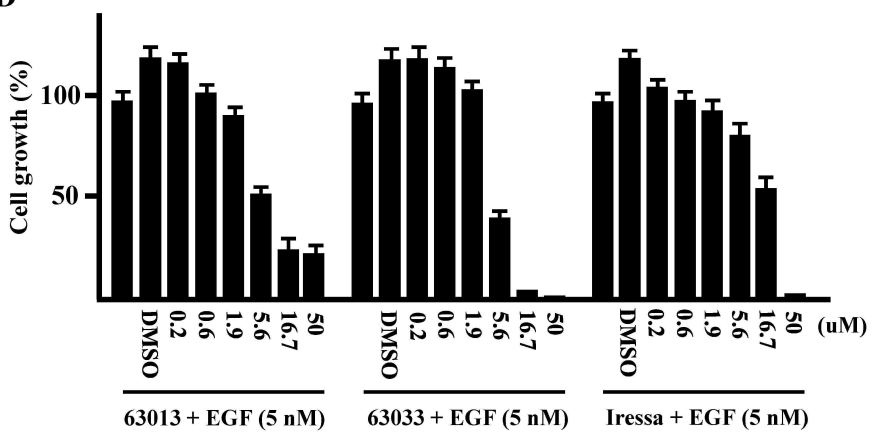

Fig. 6. Inhibition effects of each compound on the growth of EGF-induced cells. To investigate whether EGF can induce cell growth under the condition of with (A) or without (B) serum, we used various human cell lines such as A431, HeLa, A549 and SK-BR-3, which have been reported to express EGFR. (C) A431 cells were incubated in DMEM that contained various concentrations of EGF and the changes of cell growth were detected by MTT assay. (D) A431 cells were cultured in the media supplemented with $5 \mathrm{nM}$ EGF and various concentrations of each compound as indicated and the growth of cells were determined by MTT assay. All the experiments were performed in triplicate. 
A

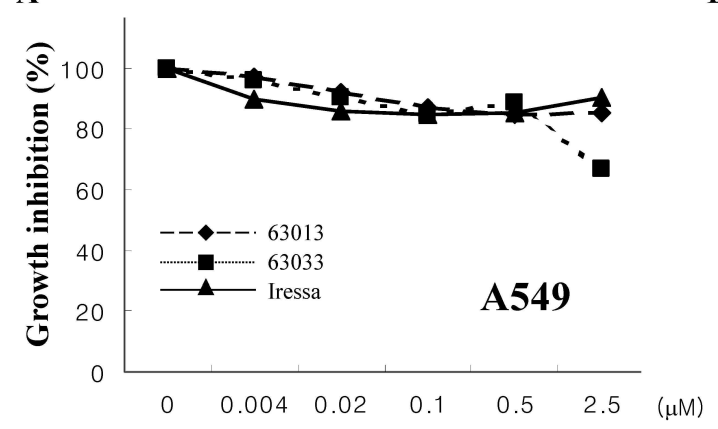

B

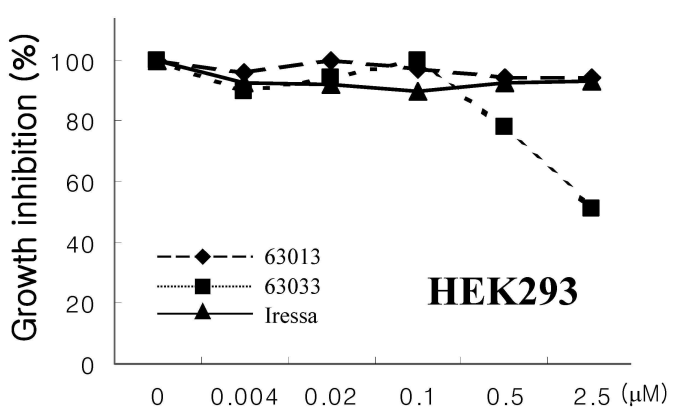

C

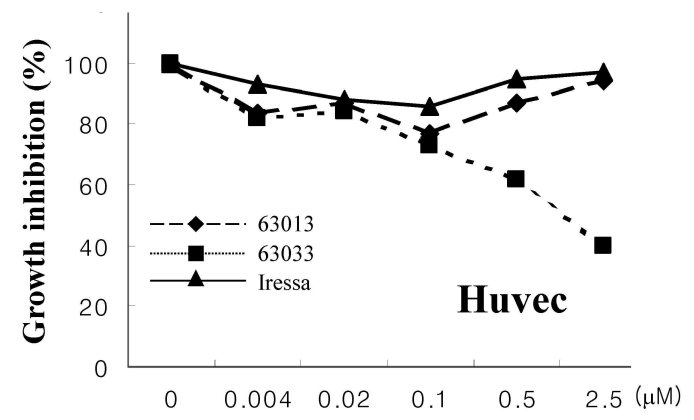

Fig. 7. Cytotoxicity of 63013, 63033, and Gefitinib on the cells. The results were determined as growth inhibition (\%) of the cells as indicated. Each compound was marked as a closed diamond (63013), quadrangle (63033), and triangle (Gefitinib). These are the representative results from 3 separate experiments.

centrations of $\mathrm{EGF}$ for $48 \mathrm{hr}$ at $37^{\circ} \mathrm{C}$ in $5 \% \mathrm{CO}_{2}$. The growth of cells was detected by MTT assay. The results showed that the highest cell growth rate was observed at the $5 \mathrm{nM}$ concentration of EGF (Fig. 6C). So, all the experiments were performed with a $5 \mathrm{nM}$ concentration of EGF. We examined the effects of each compound on the growth of cells that were treated with EGF (Fig. 6D). The two compounds 63033 and 63013 at a $1.9 \mu \mathrm{M}$ concentration, respectively, showed very similar growth of cells with that of Gefitinib. However, over $1.9 \mu \mathrm{M}$ concentration, the two compounds displayed high inhibition of cell growth while Gefitinib displayed less inhibition of A431 human epidermoid cancer. (Fig. 6D) To sum up, although the two compounds 63013 and 63033 have very similar or better EGFR inhibiting effects as compared with that of Gefitinib, further research is needed for the cytotoxicity against non-cancer cells. For the cytotoxicity analysis, A549 cells that express EGFR and HEK293 and HUVEC cells that express very low level of EGFR were incubated with various concentration of each compound as indicated in Fig. 7 for $48 \mathrm{hr}$ at $37^{\circ} \mathrm{C}$ in $5 \% \mathrm{CO}_{2}$. The results are shown 63013 and Gefitinib displayed almost no cytotoxicity, but compound 63033 has a little cytotoxic effect on non-cancer and even low expression of EGFR cell lines, HEK293 and HUVEC cells at a high concentration. Further research is needed to reduce the cytotoxicity of 63033 by making changes in the side chains while maintaining the kinase inhibiting effects because it has greater growth inhibition of A431 human epidermoid cancer than Gefitinib (Iressa ${ }^{\circledR}$ ) does.

\section{Acknowledgment}

This research was supported by the National Research Foundation of Korea Grant funded by the Korean Government (KRF-2008-314-F00048).

\section{References}

1. Arteaga, C. L. 2002. Epidermal growth factor receptor dependence in human tumors: more than just expression? Oncologist 7, 31-39.

2. Berclaz, G., H. J. Altermatt, V. Rohrbach, A. Siragusa, E. Dreher, and P. D. Smith. 2001. EGFR dependent expression of STAT3 (but not STAT1) in breast cancer. Int. J. Oncol. 
19, 1155-1160.

3. Bill, H. M., B. Knudsen, S. L. Moores, S. K. Muthuswamy, V. R. Rao, J. S. Brugge, and C. K. Miranti. 2004. Epidermal growth factor receptor-dependent regulation of integrin-mediated signaling and cell cycle entry in epithelial cells. Mol. Cell Biol. 24, 8586-8599.

4. Carpenter, G., and S. Cohen. 1990. Epidermal growth factor. J. Biol. Chem. 265, 7709-7712.

5. Casalini, P., M. V. Iorio, E. Galmozzi, and S. Menard. 2004. Role of HER receptors family in development and differentiation. J. Cell Physiol. 200, 343-350.

6. De Luca, A., S. Pignata, A. Casamassimi, A. D’Antonio, C. Gridelli, A. Rossi, F. Cremona, V. Parisi, A. De Matteis, and N. Normanno. 2000. Detection of circulating tumor cells in carcinoma patients by a novel epidermal growth factor receptor reverse transcription-PCR assay. Clin. Cancer Res. 6, 1439-1444.

7. Ha, J. D., S. K. Kang, K. D. Kim, J. K. Choi, J. Y. Kong, and C. H. Ahn. 2005. Design and synthesis of novel epidermal growth factor receptor kinase inhibitors. Bull. Korean Chem. Soc. 26, 959-965.

8. Hamid, O. 2004. Emerging treatment in oncology: focus on tyrosine kinase (erbB) receptor inhibitors. J. Am. Pharm. Assoc. 44, 52-58.
9. Herbst, R. S. 2004. Review of epidermal growth factor receptor biology. Int. J. Radiat. Oncol. Biol. Phys. 59, 21-26.

10. Klapper, L., H. Waterman, M. Sela, and Y. Yarden. 2000. Tumor-inhibitory antibodies to HER-2/ErbB-2 may act by recruiting $\mathrm{c}^{-} \mathrm{Cbl}$ and enhancing ubiquitination of HER-2. Cancer Res. 60, 3384-3388.

11. Olayioye, M. A., R. M. Neve, H. A. Lane, and N. Hynes. 2000. The ErbB signaling network: Receptor heterodimerization in development and cancer. EMBO J. 19, 3159-3167.

12. Ranson, M., L. A. Hammond, D. Ferry, M. Kris, A. Tullo, P. I. Murray, V. Miller, S. Averbuch, J. Ochs, C. Morris, A. Feyereislova, H. Swaisland, and E. K. Rowinsky. 2002. ZD1839, a selective oral epidermal growth factor receptor-tyrosine kinase inhibitor, is well tolerated and active in $\mathrm{pa}^{-}$ tients with solid, malignant tumors: results of a phase trial. J. Clin. Oncol. 20, 2240-2250.

13. Yarden, Y. and M. Sliwkowski. 2001. Untangling the ErbB signaling network. Nat. Rev. Mol. Cell Biol. 2, 127-137.

14. Sedlacek, H. H. 2000. Kinase inhibitors in cancer therapy. A look ahead. Drugs 59, 435-476.

15. Woodburn, J. R. 1999. The epidermal growth factor receptor and its inhibition in cancer therapy. Pharmacol. Ther. 82, 241-250.

\section{초록 : A431 피부암세포의 EGFR kinase 신호체계에 선택적으로 작용하는 새로운 퀴나졸린계 억제제 \\ 정철우 ${ }^{1} \cdot$ 손병화 ${ }^{2} \cdot$ 하재두 $^{3} \cdot$ 김군도 $^{1}$ * \\ ( ${ }^{1}$ 부경대학교 자연과학대학 미생물학과, ${ }^{2}$ 부경대학교 자연과학대학 화학과, ${ }^{3}$ 한국화학연구원)}

EGFR kinase의 활성을 억제할 수 있는 억제제는 암뿐만이 아니라 성장성 질환에도 효과적인 치료제가 될 수 있다. 본 연구는 새로운 퀴나졸린계 물질인 화합물 63013과 63033의 EGFR kinase 활성억제 효과를 분석하였다. 이들 물질들은 기존의 디알콕시퀴나졸린의 용해성을 증가시키기 위하여 [1,4]-다이옥시노 퀴나졸린 구조를 가지 며 알콕시 곁사슬로 연결되어있다. 화합물 63013과 63033은 A431 인간 피부암세포에서 $\mathrm{EGF}$ 에의해 유도되는 $\mathrm{EGFR}$ 의 kinase 활성을 저해, 세포 내에서 $\mathrm{EGFR}$ 신호체계에 관여하는 MEK1/2, MAPK p44/42, AKT, STAT3과 같은 하위 분자들의 활성저해 효과를 유도하였다. 이러한 활성저해 효과는 현재 상용화되어 있는 Gefitinib (Iressa ${ }^{\circledR}$ )와의 비교연구에서 화합물 63013과 63033이 보다 더 낮은 처리 농도에서 EGFR kinase의 활성을 저해하 며 암세포의 성장을 억제함을 관찰 할 수 있었다. 따라서 본 연구는 이들 신규 물질들의 EGFR-연관 질환에 대한 EGFR kinase 선택적 억제제로서의 이용 가능성을 제시하고 있다. 